\section{EXHIBITION \\ The art of arthropods}

\author{
Nick Thomas \\ A Californian entomologist uses \\ insects as living paintbrushes to \\ create abstract art. After loading \\ water-based, non-toxic paints on to \\ the tarsi and abdomens of insects, \\ Steven Kutcher directs his bugs to \\ create their 'masterpieces'. \\ Kutcher controls the direction \\ and movement of his arthropods \\ - such as hissing cockroaches \\ (pictured), darkling beetles and \\ grasshoppers - by their response \\ to external lighting. The result is \\ controlled and random movements, \\ created in a co-authorship between \\ the artist - with predetermined \\ ideas about colour, form, shape \\ and creative flexibility - and his \\ living brushes. \\ Kutcher's art is more than just \\ a novelty, because it reveals the \\ hidden world of insect footprints. \\ "When an insect walks on your \\ hand, you may feel the legs move \\ but nothing visible remains, only a
}

sensation," he says. "These works of art render the insect tracks and routes visible, producing a visually pleasing piece."

An insect-lover from childhood, Kutcher has a master's degree in entomology and has taught biological sciences at various US colleges. Since the 1970s, he has worked as a 'bug wrangler' on some 500 movies, TV shows and advertisements, where he also used hair dryers, electric tape, and chemical repellents and attractants to control insect movement. He manipulated the tiny Steatoda grossa spider (painted blue and red) that nipped actor Tobey Maguire in Spiderman.

The idea for Kutcher's bug art originated in 1985, when he was hired to create fly footprints by making a fly walk through ink for an advertisement for Steven Spielberg's television series Amazing Stories.

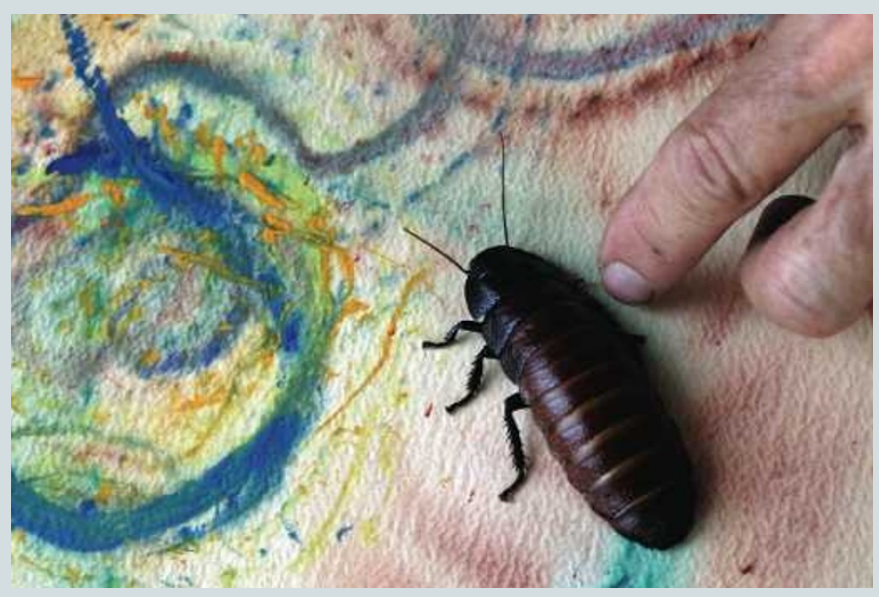

This unique artist-arthropod partnership has so far yielded over a hundred works, typically characterized by vibrant, eyecatching colours and designs, splattered with trailing dots and dashes (see www.BugArtbySteven. com). Kutcher is now gathering pieces to form a travelling exhibit for art and natural history museums throughout the United States.

"I hope people will look at these works and see the duality of art and science," he says. "Each insect is writing a page in its life, and every painting is a new discovery." Nick Thomas is associate professor of chemistry at Auburn University, Montgomery, Alabama 36124, USA.

Kutcher's bug art is on display at the Entomological Society of America meeting in San Diego (912 December) and at the Lancaster Museum (15 December-13 January 2008), in California.

\title{
On a molecular mission
}

Elizabeth Blackburn and the Story of Telomeres: Deciphering the Ends of DNA by Catherine Brady

MIT Press: 2007. 424 pp. \$29.95/£19.95

\section{Maria A. Blasco}

"I want to understand how living things work," declared a young Liz Blackburn to Frank Hird, her supervisor at the University of Melbourne, when asked why she wished to pursue a scientific career. Back in the 1960s, Blackburn could not have imagined that she would later be the main player in two fundamental discoveries in biology: the molecular nature of the ends of chromosomes, or telomeres, and the identification of the enzyme telomerase.

Catherine Brady's biography is a pageturner from the first chapter, weaving together the heroine's personality with her success as a scientist. We learn about Blackburn's family and her first tentative steps in the science world that eventually led to the discovery of telomerase in the mid-1980s, and about her determination, her curiosity, her way of dealing with situations and her opinions on the peer-reviewing process.

In highlighting the factors that shaped Blackburn's career, we follow her incursions into policy-making and science ethics: first as president of the American Society of Cell Biol-

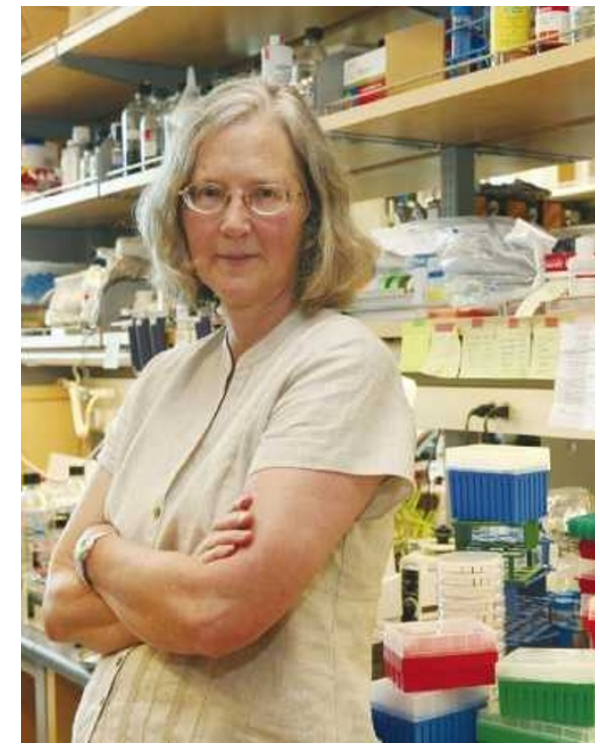

Arm arrangement: Liz Blackburn, discoverer of telomeres and telomerase, in her laboratory.

ogy (ASCB) and as the chair of the Department of Microbiology and Immunology at the University of California in San Francisco (UCSF), and then as part of the Bioethics Advisory Council to President George W. Bush - from which she was dismissed for her views on stemcell policy.
Blackburn has been an inspiration to those of us who started out in the field of telomeres. The book conveys a vivid impression of her that matches a personal encounter. Her equable temperament does not prevent her from having strong views, and she emerges as a valuable role model in the sometimes unsettling treatment of women in the world of science.

Born the second daughter of seven children in Tasmania, Australia, to a family of professional scientists (her parents were medical practitioners and her grandfather and greatgrandfather were geologists in China). An early interest in chemistry and biochemistry propelled her to Hird's lab for her doctorate, which matured her forceful scientific mind and reaffirmed her interest in science as a modus vivendi. Then Blackburn went on to what at the time was the Olympus of molecular biology, the Medical Research Council (MRC) laboratory in Cambridge, a place packed with past and future Nobel laureates that would become the gold standard for today's top scientific institutions.

The MRC laboratory was hosting a revolution in molecular biology, powered by discoveries about cellular mechanisms fundamental to life. Fred Sanger's DNA-sequencing work particularly attracted Blackburn, and from him she learned her pragmatic approach to science. As Brady points out, the heady ambience of the laboratory was marred by some male chauvinism (with Watson and Perutz receiving special mention). Blackburn discovered how things 